\title{
GENETIC DIVERSITY ANALYSIS OF THERMOPHILIC BACTERIA FROM CANDRADIMUKA CRATER IN CENTRAL JAVA EMPLOYING PCR-RFLP OF 16S-rRNA GENE
}

\author{
TEMMY DESILIYARNII ${ }^{1+}$, ANTONIUS SUWANTOAAAO $^{2,34^{*}}$, MAGGY T. SUHARTONO ${ }^{3}$, AND \\ TRESNAWATI PURWADARIA \\ 'Graduate School, Bogor Agricultural University, Bogor, Indonesia \\ ${ }^{2}$ Department of Biology, Faculty of Science and Mathematics, Bogor Agricultural University, Jl. Raya \\ Pajajaran, Bogor, Indonesia ${ }^{3}$ Inter University Center for Biotechnology, $\mathrm{Jl}$. \\ Puspa Tromol Pos 1 Darmaga, Bo gor Agricultural \\ University, Bogor, Indonesia \\ ${ }^{4}$ SEAMEO-BIOTROP, Jl. Raya Tajur, Km. 6 Bogor, Indonesia "Research Institute for Animal \\ Production, PO Box 221 Bogor 16002, Indonesia
}

\begin{abstract}
The specific primers for bacteria (63f and 1387r) were used to amplify the 16S-rRNA genes from total community genomic DNA of thermophilic bacteria. The total community genomic DNA was obtained from muds and water samples of Candradimuka crater, Dieng Plateau, Central Java. PCR products were cloned into vector pCR*2.1-TOPO (3.9 kb) and transformed into Escherichia coli TOPIC. Two tetrameric restriction endonucleases Rsal and Hhal were employed to generate Restriction Fragment Length Polymorphisms (RFLP) paterns. These enzymes yielded 10 and 9 groups of 16S-rRNA profiles or OTU (Operational Taxonomic Units) from 27 16S-rRNA gene clones. Rsal was found to be more discriminative in differentiating the clones than Hhal. Rsal-RFLP indicated that OTU 7 and OTU 3 represented the most abundant clones, i.e. 6 and 5 clones respectively. The distribution of 16S-rRNA gene clones could indicate relative distribution of specific groups of thermophilic bacteria in their natural habitat. Analysis of diversity at the DNA level could represent both culturable and unculturable bacteria in the environment. Similarity analysis showed that at level 0.600 there were 8 different groups from 10 RFLP profiles generated by Rsal digestion. This study indicated that there were at least 8 groups of different thermophilic bacteria occupying Candradimuka crater.
\end{abstract}

Key words: Thermophiles, 16S-rRNA, Candradimuka crater.

\section{INTRODUCTION}

Sustainability of the biosphere on our planet depends on microbial activities. However, we know very little about the microbial world. The reason for this poor understanding lies in the fact that microbes are tiny and individually invisible to the eye. Until recently, microbial identification required isolation of pure cultures followed by a series of physiological tests and biochemical characterization. The pure culture approach has limited our view of microbial diversity in the world, since

\footnotetext{
' Corresponding Author; E-mail address : asuwanto@indo.net.id

* Present Address : Mercu Buana University, Jl. Meruya Selatan, Jakarta.
} 
it has been known that approximately only $1 \%$ of microorganisms in the environment could be cultured (Amann et al. 1995; Pace 1997; Borneman et al. 1996). Microorganisms are involved in many important activities such as soil formation, toxin removal, biogeochemical cycles of carbon, nitrogen, phosphor and others, conservation of more complex species, and to serve as valuable materials to many industries. Environmental stresses can alter microbial population and therefore endanger biosphere health.

In the absence of systematic approaches to studying and ensuring survival of diverse microorganisms, perhaps the best approach is to preserve as many habitats as possible, especially those from extreme environment which may have unique microorganisms (Fox 1994; Borneman et al. 1996). One of the extreme environments is thermal environment which could be found in natural and artificial systems such as volcanic region, coal refuse piles, hydrothermal vents and geothermal power plants (Stetter 1995). Species diversity of the thermophilic organisms is found in both the Domain of Bacteria and Archaea. Thermophilic bacteria exhibit a wide range of nutritional capability such as phototrophy and chemotrophy; autotrophy and heterotrophy; chemolitotrophy and chemo-organotrophy; aerobiosis and anaerobiosis (Brock 1986).

The application of molecular approaches to assess bacterial diversity is now entering the exponential growth. These approaches have overcome the requirement for prior cultivation. The most widely used technique to amplify the gene coding for 16SrRNA from environmental samples relies on the application of PCR (Service 1997; Marchesi et al. 1998). For identification purposes, hypervariable regions of rKNA molecule are particularly useful due to relatively high differences between species but relatively low variability within species. Currently, there are more than 4000 16SrRNA entries in the database, covering about 1800 species which continue to grow (Bottger 1996; Amann et al. 1994). Hypervariable regions are also the regions with the most concentrated polymorphism for restriction fragment length polymorphisms (RFLP) purposes (Green 1998). The highly conserved regions of the rRNA molecule can serve as primer binding sites for in vitro amplification by PCR (Amann 1994). PCR primers designed and evaluated by Marchesi et al. (1998) i.e. . 63f (5'-CAG GCC TAA CAC ATG CAA GTC) and 1387r (5'-GGG CGG WOT GTA CAA GGC) could amplify 1300 bp of a consensus 16S-rRNA genes from bacteria.

In our study, we attempt to explore genetic diversity of thermophilic bacteria with PCR-RFLP of 16S-rRNA genes from environmental DNA. RFLP analysis was conducted using tetrameric endonucleases Rsal (5'-GTlAC) and Hhal (5'-GCGiC). These enzymes along with BstUl were described by Moyer et al. (1996) as the most efficacious at detecting and differentiating bacterial Small Sub Unit rRNA genes on the basis of their ability to correctly classify Operational Taxonomic Units (OTU). In this study, we have also analyzed partial 16S-rRNA sequences of two dominant OTU in Candradimuka crater. 
Genetic diversity analysis of thermophilic bacteria - Temmy Desiliyarni et al.

\section{MATERIALS AND METHODS}

\section{Sample collection}

Candradimuka crater is located in Dieng Plateau (above $2000 \mathrm{~m}$ from sea level), Central Java, Indonesia. Sample was collected from a small pool (Cl site) characterized by almost boiling hot spring with temperature of $88^{\circ} \mathrm{C}$ and $\mathrm{pH} 7$ (Fig. 1). Water and sandy-mud were collected in a $250 \mathrm{ml}$ sterile bottle, tightly sealed, and transported within 24 hours for immediate processing.

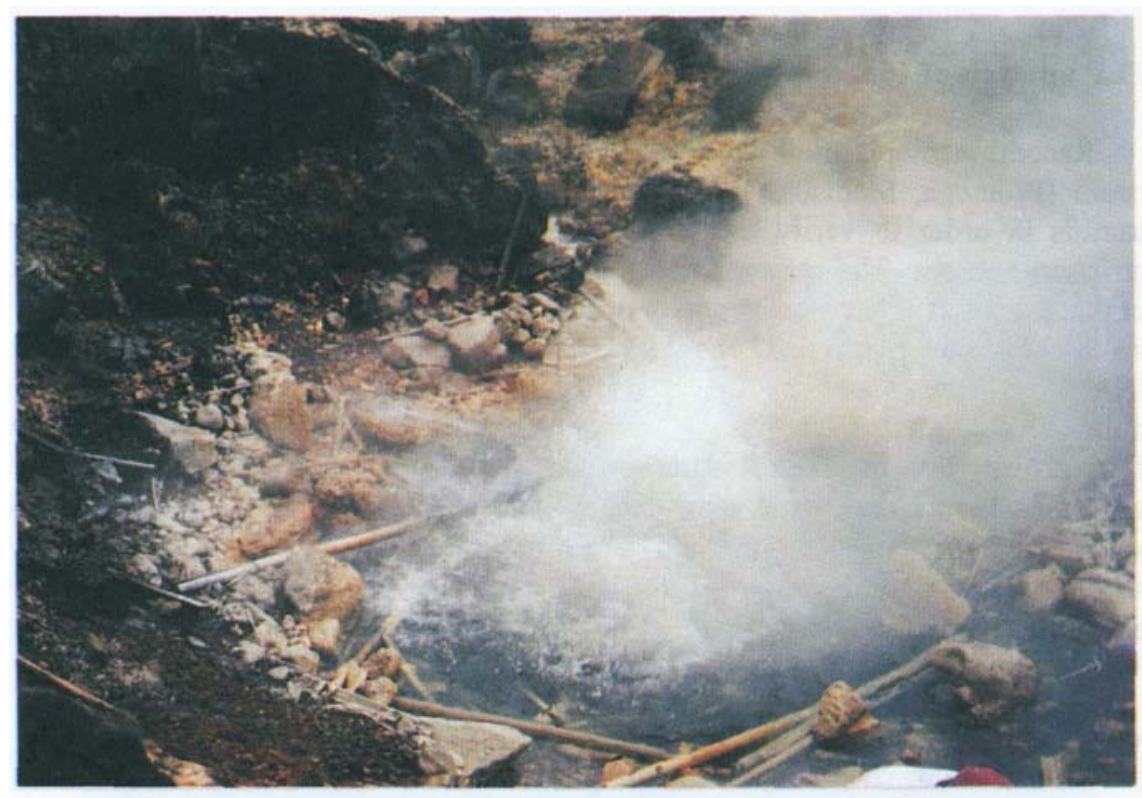

Figure 1. Profile of Cl Site in Candradimuka crater, Dieng Plateau, Central Java.

\section{Extraction and purification of genomic DNA}

Approximately $5 \mathrm{~g}$ of sample was extracted as described by Zhou et al. (1996) and modified by Tiedje (1997, unpublished). The crude DNA obtained was purified with the Prep-A-Gene kit(Biorad, Richmond, CA).

\section{Amplification and cloning of 16S-rRNA genes}

The 16S-rRNA genes were PCR-amplified by specific primers for Bacteria (63f and 1387r) from purified genomic DNA (200 ng) using Ready-To-GO PCR 
Beads (Pharmacia-Biotech). Total volume of PCR reaction contained 1.5 U Tag DNA Polymerase, lOmM Tris- $\mathrm{HCl}$ (pH 9 at room temperature), $50 \mathrm{mM} \mathrm{KC1,} 1.5 \mathrm{mM}$ $\mathrm{MgCl}_{2}, 200 \mathrm{uM}$ of each dNTPs and stabilizer including BSA. The reaction was incubated in Gene Amp PCR System 2,400 Thermocycler (Perkin-Elmer Cetus, Norwalk, Conn.)- The PCR protocol was: pre-PCR at $94^{\circ} \mathrm{C}$ for $2 \mathrm{~min}$, denaturation at $92^{\circ} \mathrm{C}$ for $30 \mathrm{~s}$, annealing at $55^{\circ} \mathrm{C}$ for $30 \mathrm{~s}$, elongation at $75^{\circ} \mathrm{C}$ for $1 \mathrm{~min}$ and post-PCR at $75^{\circ} \mathrm{C}$ for 5 min with a total of 30 cycles (Marchesi et al. 1998).

The PCR product was cloned into pCR®2.1-TOPO (3.9 kb), and transformed into competent $E$. coli TOP 10 using TOPO TA Cloning kit (Invitrogen Corp.). The positive clones were screened for a-complementation and selected as white colonies.

RFLP analysis of 16S-rRNA genes

Recombinant plasmids were isolated using the Wizard Plus SV Miniprep System (Promega, Madison, WI). EcoRI and Rsal were employed to digest the plasmids in order to verify the cloned DNA and to classify according to their restriction patterns. The reason for selecting these two enzymes was based on the fact that the insert DNA was cloned between two sites of EcoRI and there are $3 \mathrm{Rsal}$ sites in the vector plasmid. Clones that contained approximately 1,300 bp of 16S-rRNA genes were chosen for RFLP analysis. These clones were subsequently PCR-amplified, restricted by tetrameric endonuclease $\mathrm{Rsal}$ and $\mathrm{Hhal}$ to detect the different restriction profiles. Restriction enzyme digestion was performed at $37^{\circ} \mathrm{C}$ for 6 hours before they were separated by gel electrophoresis in $2 \%$ agarose gel, stained with $0.5 \mathrm{ug}$ of ethidium bromide per $\mathrm{ml}$ and visualized by UV transilluminator (Sambrook et al. 1989). RFLP profiles obtained from Rsal digestion were used to generate dendrogram reflecting their genetic relationship employing UPGMA clustering method from NTSys program (Rohlf 1990).

DNA Sequencing of 16S-rRNA genes

Genes for 16S-rRNA from two dominant OTUs were partially sequenced to infer the closest related organism from RDP database. The sequencing reactions were done using the Big Dye Ready Reaction Dye Deoxy Terminator kit and purification using ethanol-sodium acetate precipitation. The reactions were run on an ABI PRISM 377 DNA Sequencer (Perkin-Elmer Cetus, Norwalk, Conn.).

\section{RESULTS AND DISCUSSION}

Screening for a-complementation yielded 36 white colonies (transformants). Recombinant plasmids from all of these transformants were extracted. Verification of the clones containing an insert DNA (16S-rRNA gene) using Rsal generated 19 groups of restriction profiles. Thus, we used these 19 groups for subsequent RFLP 
analysis. A total of 16 groups (representing 27 clones) contained the entire $1.3 \mathrm{~kb}$ to 1.35 kb 16S-rRNA insert after PCR-amplification using amplimers 63f and 1387r.

Two tetrameric restriction endonucleases were employed to differentiate RFLP profile from 16S-rRNA genes of 16 groups mentioned above in order to identify every object to be classified as OTU or a strain in most bacteriological works (Logan 1994). The RFLP profiles resulted from Rsal digestion generate 10 OTUs (Fig. 2) which were: OTU 1 (clone number 1, 2, 5, 31), OTU 2 (number 3), OTU 3 (number 4, 10, 14, 21, 32), OTU 4 (number 6), OTU 5 (number 9), OTU 6 (number 7, 8), OTU 7 $(16,18,19$ 25, 26, 34), OTU 8 (number 17, 20), OTU 9 (number 12, 15, 27, 36) and OTU 10 (number 30). Two dominant OTUs are OTU 7 (6 clones) and OTU 3 (5 clones). In evaluating these profiles, we identified discrete patterns that are specific for a clone and could be distinguished one from another as an OTU. Results from these data infer that bacteria belonging to OTU 7 and OTU 3 were distributed relatively wide and dominant at the habitat of Candradimuka crater.

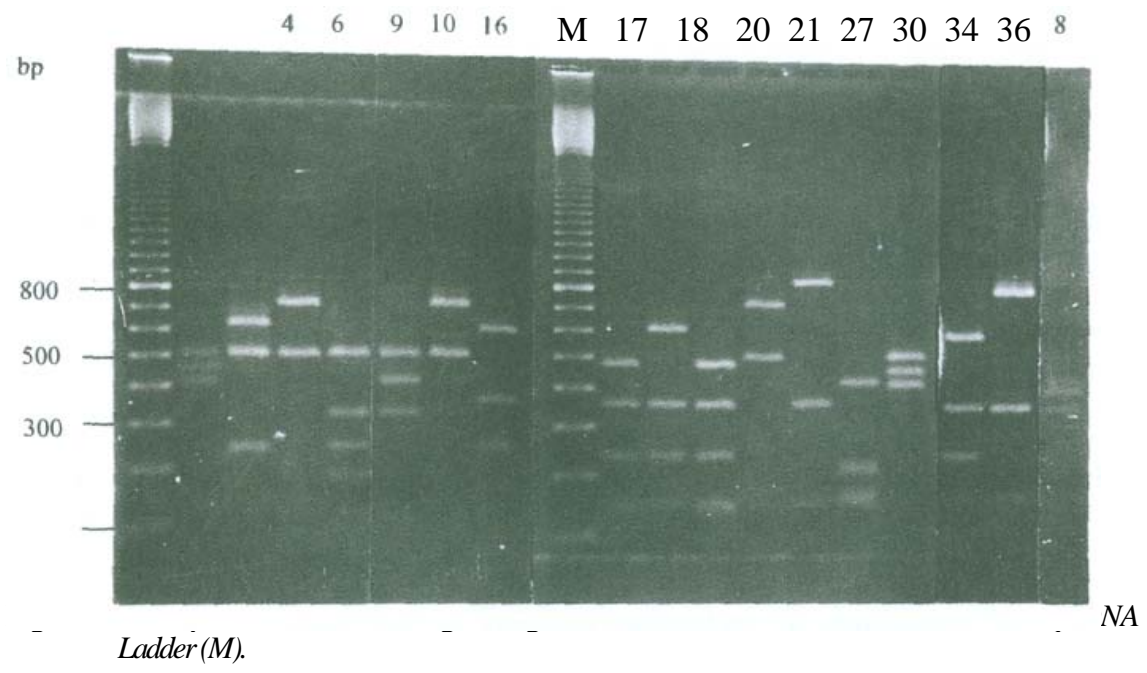

The second digestion of 16S-rRNA gene using Hhal produced 9 OTU (Fig. 3). The grouping of restriction profiles was the same as Rsal except that OTU 7 and OTU 8 (from foal-RFLP) were in the same group in ///zal-RFLP. The result of RFLP using these two enzymes indicated that Rsal was more discriminative than Hhal to differentiate the clones, in this case for bacterial strains from Candradimuka crater belonging to OTU 7 and OTU 8. This result was in agreement with the one conducted by Moyer et al. (1996) that Hhal, Rsal and BstUl were the most 
BIOTROPIA No. 14, 1999

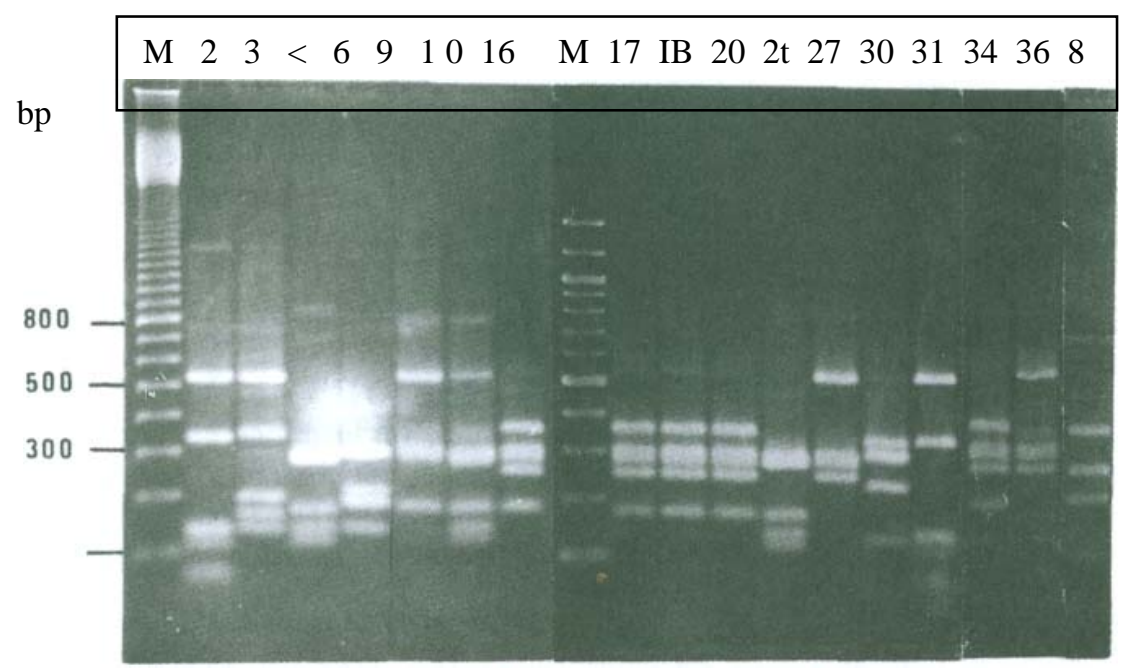

Figure 3. RFLP profile of 16S-rRNA gene digested with Hhal. Molecular standard is 100 bp DNA Ladder (M).

efficacious enzymes at detecting and differentiating 16S-rRNA genes originated from environmental DNA.

Our result indicated that at least 10 OTUs were present in Candradimuka site $\mathrm{Cl}$ which reflected the relative abundance of bacteria in this extreme habitat, in contrast to only two culturable clones obtained on Thermophilic Maintenance medium incubated at $\mathrm{pH} 1$ and temperature of $70^{\circ} \mathrm{C}$ under aerobic condition. Research conducted by Huber et al. (1991) with samples taken from three sites of Candradimuka crater obtained two hyperthermophilic Archaea, i.e. Thermoproteus and Desulfurococcus and novel anaerobic obligate bacteria having chemolitotrophy $\mathrm{H}_{2} / \mathrm{NO}_{3}$ ". The use of amplimers $63 \mathrm{f}$ and $1387 \mathrm{r}$ in this study would limit the amplification of 16S-rRNA genes only for Bacteria. Consequently, one should keep in mind that assessment of Prokaryote diversity in this study did not include members from Archaea. The reduction of 16 groups of restriction profiles to 10 OTUs from /faal-RFLP profiles could be explained with the possibility that the gene insert may have two different orientations when ligated to the vector. The difference could be determined from recombinant plasmid restriction profiles, but not for intact 16S-rRNA genes obtained from PCR. The 10 OTUs of thermophilic bacteria were analysed further using cluster analysis (Fig. 4). This dendrogram showed that at level 0.600 there were 8 groups from 10 OTUs, in that OTU 4 and OTU 5 were in one cluster as well as OTU 7 and OTU 8.

From this dendrogram, it could also be shown that at level 0.205 , there were two groups of genetic relationship. One group consisting of OTU 7, 8, 9 and 10, were in the same group with IT-08 isolate obtained from Gunung Pancar, West Java 
Genetic diversity analysis of thermophilic bacteria - Temmy Desiliyami $e$ t al.

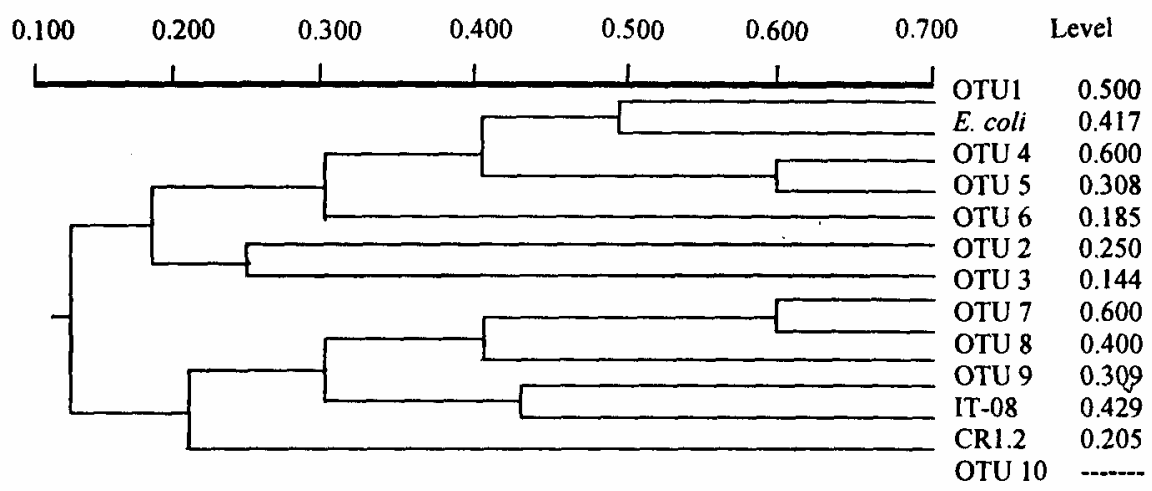

Figure 4. Dendrogram of RFLP profile of 16S-rRNA gene after digestion with Rsal. The number at horizontal axis represented \% of similarity based on Jaccard coefficient.

(Tan 1999) and CR1.2 (isolate from 16S-rRNA gene library of Candradimuka crater at Site 4). Isolate of IT-08 has the DNA sequence similar to Bacillus thermoleovorans (98\%) whereas CR1.2 has the DNA sequence similar to Brevibacterium thermoruber (99\%). The other group shows that OTU 1 was closely related to E. coli (16S-rRNA genes in pKK3535 constructed by Brosius et al., 1981 in Herawati, 1996). One possible explanation is the construction for OTU 1 and E. coli involved 3 restriction fragments which have two similar band sizes. Another explanation 'is that OTU 1 is a new bacterial isolate which yielded DNA profile similar to $E$. coli when restriction enzyme Rsal was employed in this study.

In a habitat like Candradimuka crater, there may be some dominant bacteria occupying that extreme habitat. They are physiologically active among the slow grower and dormant bacteria. Therefore, estimating genetic diversity through isolation of DNA from environmental sample is able to represent all of the organisms including unculturable ones. Although there are some biases such as different cell lysis methods and amplimer sets resulting in limited comparability to other studies, the data of 16S-rRNA genes from environmental libraries demonstrated the presence of hitherto unidentified bacteria. Only a minority of sequences retrieved from directly isolated soil DNA were reported to be closely related to cultured organisms so that bacterial communities in the environment were composed mainly of uncultured species (Felske et al. 1998).

Partial sequencing of OTU 3 (520 bp) and comparison to Ribosomal Database Project (RDP) database from the University of Illinois indicate that OTU 3 demonstrated 96\% similarity to Ocrobactrum anthropi (IAM 14119) whereas OTU 7 (450 bp) had 86\% similarity to Pseudomonas flavescens (B62(T)). DNA sequencing provides more accurate data because nucleotides are the basic unit of information, straightforward approaches for inferring phylogenetic history and very reliable to compare specific DNA fragment. Besides the advantages, this technique carries inherent drawbacks, such as relatively high cost operation and impractical for 
routine application long DNA molecule. On the contrary, PCR-RFLP technique is simple, rapid, low cost, for a 50 - 3000 bp DNA fragment range could be assayed, and especially more appropriate when many individuals need to be sampled (Hillis et al. 1996). To assess the diversity of an environmental sample using PCR-RFLP study, we do not have to use the most accurate technique like DNA sequencing. Therefore, the simpler and faster method could be valuable in taxonomic study for bacterial in situ detection and routine investigation.

\section{ACKNOWLEDGMENTS}

This research was financially supported by Hibah Tim Project (URGE) No. 005/HTPP/IV/URGE 1999/2000, and DIP SEAMEO-BIOTROP Bogor 1998/1999 to Antonius Suwanto.

\section{REFERENCES}

Amann, R.I., W. Ludwig, and K.H. Schleifer. 1994. Identification of Uncultured Bacteria: A Challenging Task for Molecular Taxonomists. ASM News. 60:360-365.

Amann, R.I., W. Ludwig, and K.H. Schleifer. 1995, Phylogenetic Identification and In Situ Detection of Individual Microbial Cells Without Cultivation. Microbiol. Rev. 59:143-169.

Anonim. 1997. TOPO TA-Cloning® Manual. Invitrogen Corp. San Diego, California.

Bomeman, J., P.W. Skroch, K.M.O'Sullivan, J.A. Palus, N.G. Rumjanek, J.L. Jansen, J. Nienhuis and E.W. Triplett. 1996. Molecular Microbial Diversity of an Agricultural Soil in Wisconsin. Appl. Environ. Microbiol. 62:1935-1943.

Bottger, E.C. 1996. Approaches for Identification of Microorganisms. ASM News. 62:247-250.

Brock, T.D. 1986. An Overview of The Thermophiles. In Brock, T.D. Thermophiles: General, Molecular and Applied Microbiology. John Wiley \& Sons. New York.

Herawati, E. 1996. Physiology and genetic characterization of luminous Vibrio causing disease on tiger prawn (Penaeus monodon fab.). Thesis, Aquaculture Program, Faculty of Fisheries, Bogor Agricultural University, Bogor.

'Felske, A., A. Wolterink, R. Van Lis and A.D.L. Akkermans. 1998. Phylogeny of The Main Bacterial 16SrRNA Sequences in Drentse A Grassland Soils (The Netherlands).- Appl. Environ. Microbiol. 64:871-879.

Fox, J.L. 1994. Microbial Diversity: Low Profile, Immense Breadth. ASM News. 60:533-536.

Green, E. K. 1998. Restriction Fragment Length Polymorphisms. In Rapley, R. and J.M. Walker. Molecular Biology Methods Handbook. Humana Press. Totowa, New Jersey.

Hillis, D. M., B. K. Mable, A. Larson, S. K. Davis and E. A. Zimmer. 1996. Nucleic Acids IV: Sequencing and Cloning. In D. M. Hillis, C. Moritz and B. K. Mable (ed.). Molecular Systematics. Sinauer Associates, Inc. Massachusetts.

Huber, G., R. Huber, B.E. Jones, G. Lauerer, A. Neuner, A. Segerer, K.O. Stetter and E.T. Degens. 1991. Hyperthermophilic Archaea and Bacteria Occurring within Indonesian Hydrothermal Areas. System. Appl. Microbiol. 14:397-404. 
Genetic diversity analysis of thermophilic bacteria - Temmy Desiliyami et al.

Logan, N. A. 1994. Bacterial Systematics. Blackwell Scientific Publ. London.

Marchesi, J.R., T. Sato, A.J. Weightman. T.A. Martin, J.C. Fry, S.J. Hiom and W.G. Wade. 1998. Design and Evaluation of Useful Bacterium-Specific PCR Primers that Amplify Genes Coding for Bacterial 16SrRNA. Appl. Environ. Microbiol. 64:795-799.

Moyer, C.L.. J.M Tiedje, F.C. Dobbs, D.M. Karl. 1996. A Computer-Simulated Restriction Fragment Length Polymorphism Analysis of Bacterial Small-Subunit rRNA Genes: Efficacy of Selected Tetrameric Restriction Enzymes for Studies of Microbial Diversity in Nature. Appl. Environ. Microbiol. 62:2501-2507.

Pace, N. R. 1997. A Molecular View of Microbial Diversity and The Biosphere. Science. 276:734-739.

Rohlf, C. L., C.C. Yeo and L. Tay. 1990. NTSys-pc, Numerical taxonomy and multivariate analysis system, version 1.60. Exeter software. New York.

Sambrook, J., E.F. Fritsch and T. Maniatis. 1989. Molecular Cloning. A Laboratory Manual. Second Edition. Cold Spring Harbor Laboratory Press.

Service, R. F. 1997. Microbiologists explore life's rich, hidden Kingdoms. Science. 275:1740-1742. Stetter, K.

O. 1995. Microbial Life in Hyperthermal Environments. ASM News. 61:285-290.

Tan, I. 1999. Characterization of a thermophilic xylanolytic bacterium isolated from Gunung Pancar hotspring. Bogor. Master Thesis, Graduate Study, Bogor Agricultural University, Bogor

Zhou, J., M.A. Brunns, and J. M. Tiedje. 1996. DNA Recovery from Soils of Diverse Composition. Appl. Environ. Microbiol. 62:316-322. 